\title{
Factors Influencing Business Intelligence Data Collection Strategies
}

\author{
HANIF FAIDZ RAHADIAN \\ DEKAR URUMSAH \\ Universitas Islam Indonesia
}

\begin{abstract}
This research purposed to examines the influence of institutional isomorphism and competitive pressure on business intelligence (BI) data collection strategies which are problem driven and comprehensive through 3 purposes of BI (insightfulness, consistency, organizational transformation). The populations of this research are managers and employees who are working at the same level as the manager at PT. Telekomunikasi Indonesia Tbk. in Witel Yogyakarta Special Region, Witel Purwokerto, and Division Digital Business Central Jakarta. Statistic tool used to test the hypothesis is the structural equation model (SEM) with SmartPLS software. Data were collected from 96 respondents which spread to three regions of Telkom office with direct questionnaire method. The result of this research shows that only BI purpose consistency that did not have a positive relation to the strategy comprehensive BI data collection strategy.
\end{abstract}

Keywords: Institutional Isomorphism, Competitive Pressure, Purpose Of BI, Comprehensive Data Collection Strategy, Problem Driven Data Collection Strategy.

Intisari: Penelitian ini bertujuan untuk menguji pengaruh isomorfisma institusional dan tekanan kompetitif terhadap strategi pengumpulan data intelijen bisnis (BI) yang didorong oleh masalah dan komprehensif melalui 3 tujuan BI (insightfulness, konsistensi, transformasi organisasi). Populasi penelitian ini adalah manajer dan karyawan yang bekerja pada level yang sama dengan manajer di PT. Telekomunikasi Indonesia Tbk. di Witel Daerah Istimewa Yogyakarta, Witel Purwokerto, dan Divisi Bisnis Digital Jakarta Pusat. Alat statistik yang digunakan untuk menguji hipotesis adalah structural equation model (SEM) dengan perangkat lunak SmartPLS. Data dikumpulkan dari 96 responden yang tersebar di tiga wilayah kantor Telkom dengan metode kuesioner langsung. Hasil penelitian menunjukkan bahwa hanya konsistensi tujuan BI yang tidak memiliki hubungan positif dengan strategi strategi pengumpulan data BI yang komprehensif.

Kata Kunci: Isomorfisma Kelembagaan, Tekanan Kompetitif, Tujuan BI, Strategi Pengumpulan Data Komprehensif, Strategi Pengumpulan Data Berbasis Masalah. 


\section{Introduction}

The development of information technology becomes faster than before. People can easily access many kinds of information everywhere and every time with supported wifi. PT. Telekomunikasi Indonesia Tbk. (2014) with one of its products named wifi.id planned to build 10.000 wifi in all over Indonesia with the average speed of $100 \mathrm{Mbps}$ in order to increase its revenue from broadband service. Then, the government effort to deliver internet facility in all over Indonesia will come true because the communication and information access between Indonesian people become easier.

Some reasons that become a problem in business so far are the changes in consumers scheme and consumers behavior, changes in market condition, future trend, social condition, government policy, and political condition. These things can support some company to invest in technological development to increase data quality, information quality, and organization performance. While the business environment is changing so fast, most organization's achievements and sustainability depend on the time used useful data, and business information (Lonnqvist and Pirttimaki, 2006). So, to face the change in business condition, an organization need the right solution to overcome the problem.

Business intelligence (BI) is an application and technology to collect, store, analyze, and provide access to data which in the end will help a company as a better business user and make a strategic decision (Turban et al., 2008). Nowadays, it can be said that $\mathrm{BI}$ is one of the solutions over the problem that happened to a decision maker, in the middle of business competition in this globalization era. Ronald (2008) stated that BI is a concept that used many kinds of technology. A BI generally involve in wide scope which are a process, software, and technical, begin with collecting the data from a source thus generating business value to users.

DiMaggio and Powell (1983) consider that institutional isomorphism as an obstacle that forces one unit in a population to resemble the other units that face the same condition. At the same time, today BI technology is widely spread in all 
industries sector include a bank, finance, insurance, manufacture and retail industries (Olszak and Zeimba, 2006). Therefore, institutional isomorphism might happen in many industries where the business user already applied BI strategy.

Competitive pressure is when the company feels the level of pressure for the competitor in industries (Zhu and Kramer, 2005). Porter and Millar (1985) observe the strategic reasons behind competitive pressure as strength to encourage innovation and diffusion. As the explanations, competitive pressure generally means as a competitive level from the competition in one industry that motivates to make innovation.

Previous research conducted by Ramakrishnan et al. (2010) about BI collecting data strategy in LIST Inc., the respondents consist of BI developer and managers, the researchers explain that the external factor which influences data collecting strategy are institutional isomorphism and competitive pressure which through three BI purpose, which are insightfulness purpose, consistencies purpose, and organization information purpose. Data from 63 respondents, the result show that three of six hypotheses have a positive influence and significant. By using fewer respondents and some indicator, the item is not qualified with the minimum AVE.

\section{Theoretical Framework and Hypothesis Development}

\subsection{Theoretical Framework}

\subsubsection{Institutional Isomorphism}

Institutional theory helps to examine organizational decision making from the perspective of the influence of external institutions (DiMaggio and Powell, 1991). The influence of external institutions and competitors in an industry has indirectly impacted the strategy taken by managers. Institutional theory suggests that organizational changes are driven more by the need to achieve legitimacy than the desire for efficiency (DiMaggio and Powell, 1983). This desire to achieve legitimacy gives rise to institutional isomorphism where organizations within the same environment become more similar without necessarily becoming more efficient (DiMaggio and Powell, 1983). 


\subsubsection{Competitive Pressure}

Competitive pressure is defined as "the degree of pressure that the company feels from competitors within the industry" (Zhu and Kramer, 2005). Given the pressures within an industry, the pressure to become superior will be higher. In a competitive environment, the companies may have a competitive advantage if adopting, innovating, and implementing the information systems by different organizations to achieve a competitive edge over other firms in the same industry (Mata et al., 1995). There are various ways in which companies cope with competitive pressures. One way is to incorporate innovations that alter the rules of competition by changing the industry structure which they operate (Millar, 1985). Technology adoption is also a way that organizations employ to address competitive pressure (Robertson and Gatignon, 1986).

\subsubsection{BI Purpose: Insightfulness}

One of the main reasons the organization embarked on BI implementation is to understand the current business and to get decision support benefits, which is the influence of BI purpose insightfulness (Ramakrishnan et al., 2010). To helps organizations, implementing BI helps to get a better understanding of strategic matters and trends that affect the business leading to informed decision-making (Gould, 2001). It would help the decision-makers to understand the current business condition. Decision makers may have this data and use it to integrated data to support decision making. Furthermore, the data were collected and integrated with individual business units within to lower the benefits of decision support. Ramakrishnan et al. (2010) examine the relation of BI insightfulness objectives with problem driven strategy.

\subsubsection{BI Purpose: Consistency}

The next reason why the organization implements $\mathrm{BI}$ is to achieve a single consistent view of business information. Getting a single consistent view of business information may compel an organization to initiate a BI project to improve its data quality, eradicating inconsistency in data, and providing a single version of the truth 
(Eckerson, 2003). So that, the purpose of this strategy is to provide a single version of the truth that can help in enhancing decision performance within the organization and may improve high-quality data and avoid inconsistencies to comply with existing regulations. Also, implementing a comprehensive data collection strategy is very time consuming and expensive (Watson and Haley, 1998). Therefore, if the aim of starting BI is to get a single consistent view, it is necessary to use a comprehensive data collection strategy for BI data collection. Ramakrishnan et al. (2010) examines the relation of BI implementation's goals which consistence with a comprehensive strategy.

\subsubsection{BI Purpose: Organizational Transformation}

The third reason why organizations implement $\mathrm{BI}$ is to help in organizational transformation. Here organizations develop a new business model to take advantage of an external market or to achieve a competitive advantage over other organizations within the same industry (Anderson-Lehman et al., 2004). Organizational transformation is enabled by redefining business objectives and aligning these business objectives with IT objectives (Henderson and Venkatraman, 1993). To do so, it is essential to understand and manage the flow of entire data within the enterprise (Bergeron et al., 2004). Therefore, it is critical for organizations to have a consolidation view of his company data to realize organizational transformation. So, the organization adopts a comprehensive data collection strategy to enable organizational transformation.

When organizations implement BI to realize organizational transformation, it is necessary for them to have a consolidated view about his company data widely. They use a comprehensive data collection strategy to collect and integrate data from BI. In according to previous research conducted by Ramakrishnan et al., (2010) examines the relation of the BI goals of organizational transformation in BI with a comprehensive strategy.

\subsubsection{Problem Driven Strategy in BI Data Collection}

The problem-driven strategy involves the collection and integration of data 
to provide solutions for a particular business unit initially. This usually happens in response to some of the problems faced by business units or organizations. The driving force behind such a strategy is a single or a small set of applications that can provide potential benefits (Watson and Haley, 1998). Here, the BI application is seen as a great problem-solving tool that can enable access to relevant integrated data and thus enhance the decision-making process of individual business units (Massa and Testa, 2005). The problem-driven strategy takes an application-centric approach where the application required to solve the specific problems drives the collection and integration of relevant data sources (Sen and Sinha, 2005).

\subsubsection{Comprehensive Strategy in BI Data Collection}

The first strategy involves collecting, integrating, and storing all the data present in the organization into a single repository called the enterprise-wide data warehouse (Ariyachandra, and Wathson, 2005). Extensive infrastructure planning is required for implementing this strategy (Ariyachandra and Watson, 2005). The organizations need space to accommodate data on a large scale because the data input in warehousing would be more significant in the future. This strategy is consisting of collecting, integrating and storing most of the organization's data into data warehousing, and a strategy called a comprehensive data collection strategy. Comprehensive data collection strategies require a data-centric approach in which data are collected, integrated, and then tested (Moss and Atre, 2003).

\subsection{Hypotheses Formulation}

\subsubsection{Institutional Isomorphism and BI Purpose}

Institutional theory suggests that once a technology becomes widespread, then organizations adopt that technology to gain legitimacy within the industry rather than improving efficiency (DiMaggio and Powell, 1983). Normative isomorphism relates to the pressure exercised by professional associations by creating a cognitive base and legitimization for the autonomy of the industry (Lai et al., 2006). Furthermore, institutional isomorphism can also happen in an indirect way such as the backing of 
high authority or top management (Roy and Seguin, 2000). In such cases failure to take advantage of the resources available to implement technology such as BI that has a high face value (Anderson-Lehaman, 2004) can be interpreted as a sign of incompetence (Roy and Seguin, 2000). Institutional isomorphism can also stem from organizations copying the best practices of other organizations that they perceive to be successful (Lai et al., 2006). Organizations generally try to imitate other organizations when they are faced with uncertainty and when their understanding of technologies is weak (DiMaggio and Powell, 1983). Besides, best practices for implementing BI and the benefits of decision support can be replicated by implementing BI. In this way, institutional isomorphism can influence the organization to implement BI to lower the profits of decision support. Based on the explanation, this research hypothesis is:

\section{H1: Institutional isomorphism has a positive relation to the BI purpose insightfulness.}

H2: Institutional isomorphism has a positive relationship to the BI purpose consistency.

\subsubsection{Competitive Pressure and BI Purpose Organizational Transformation}

Competitive pressure has been recognized as an essential factor in the adoption, innovation, and implementation of information systems by different organizations to achieve a competitive edge over other firms operating within the same industry (Zhu and Kramer, 2005). It drives businesses to be highly innovative and has shown to increase the likelihood of innovation adoption (Thong, 1999). It also increases the uncertainty within the industrial environment and thereby increases the necessity to implement new information systems to deal with this uncertainty (Ettlie and Bridges, 1982). Based on the explanation, this research hypothesis is:

H3. BI purpose competitive pressure has a positive relation to the BI purpose organizational transformation. 


\subsubsection{BI Purpose Insightfulness and Problem Driven Strategy}

The primary goal of the organization embarking on $\mathrm{BI}$ implementation is to understand current business and to derive decision-support benefits, i.e., leverage BI insightfulness attribute (Ramakrishnan et al., 2010). BI aids in getting a better understanding of strategic matters and trends that affect their business (Gould, 2001). That would make decision-makers can get the data and then integrated it to support decision making. Furthermore, data is also collected and integrated with individual business units within an organization to lower the benefits of decision support. Based on the explanation, this research hypothesis is:

H4. BI purpose insightfulness has a positive relation to the problem-driven strategy in BI data collection.

\subsubsection{BI Purpose Consistency and Comprehensive Strategy}

The second purpose of the organization that implementing BI is to provide a point of view about the company to the stakeholders. This relates to data governance and initiates a BI project to improve data quality and to eliminate inconsistencies (Eckerson, 2003). Thus, organizations implement BI to obtain high-quality data and avoid inconsistencies to comply with the existing regulations.

Also, a single and comprehensive integrated view of broad enterprise data also enables time-saving during data analysis and provides users to develop their own applications to leverage this integrated information (Watson, 2004). Based on the explanation, this research hypothesis is:

H5. BI's consistency objectives have a positive relation to the comprehensive strategy in BI data collection.

\subsubsection{BI Purpose Organizational Transformation and Comprehensive Strategy}

The organizational purpose that implemented BI in this study was to help organizational transformation. (Anderson-Lehman et al., 2004) Organizational transformation is possible by aligning the definition of business objectives and aligning these business objectives with IT goals (Henderson and Venkatraman, 1993). Therefore, to understanding and managing the flow of data within the company (Bergeron et al., 2004). Consequently, it is essential for the organization to have a vision.

A strategic organization is for organizational transformation. Thus, when the organization implements BI to realize organizational transformation, it is necessary 
for them to have a view. They use comprehensive data strategies to collect and integrate data from BI. Prior research conducted by Ramakrishnan et al. (2010) relation about the goals of BI organizational transformation with strategy. Based on the explanation, this research hypothesis is:

H6. The goals of BI organizational transformation have a positive relation to the comprehensive strategy in BI data collection.

Figure 1

Research Model

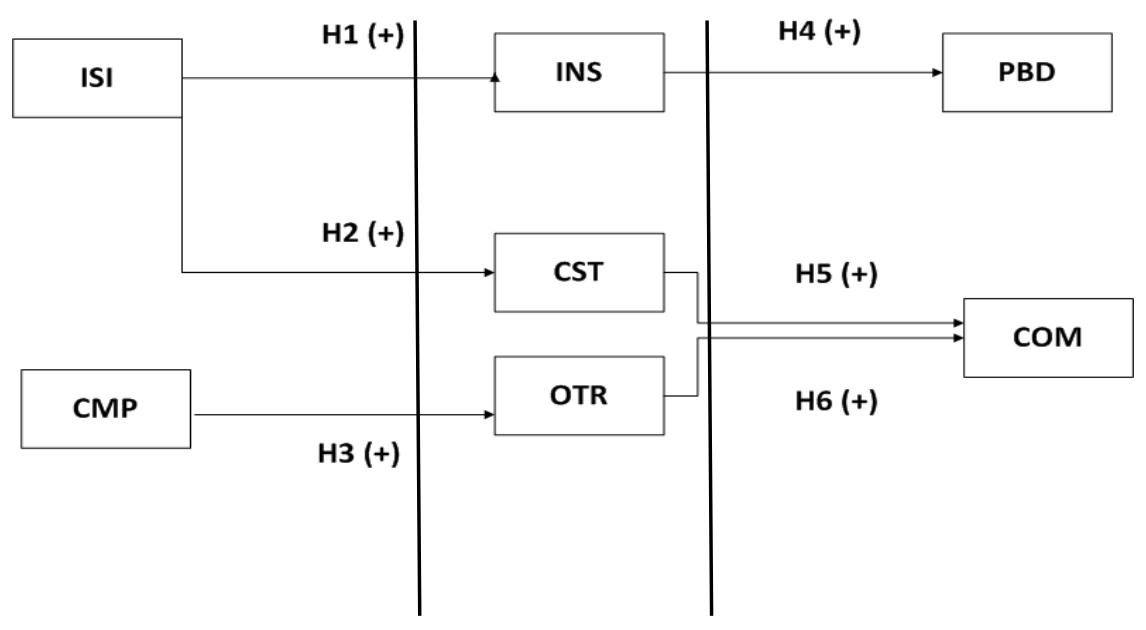

EXTERNAL FACTOR BI PURPOSE

BI DATA COLLECTION STRATEGY

\section{Research Method}

\subsection{Research Design}

This research uses a questionnaire survey method. The technique used is purposive random sampling, which is a method of determining the sample with specific characteristics that are considered to have a close relation with the characteristics - the characteristics of the population that has been known before (Ghozali, 2012). The criteria of respondents are manager and employees who have authority to decide and work in Telekomunikasi Indonesia Tbk.

\subsection{Sample and Data Collection Procedures}


This research conducted a survey using questionnaire method. The selected population is the employees of PT. Telekomunikasi Indonesia Tbk., because the company has a sub-unit room that acts as a collecting competitor's data and internal data to be processed then analyzed to take a business decision. The survey was conducted from January to February 2015, from 150 distributed questionnaires, there are 96 qualified questionnaires. The eligible questionnaire consisted of three regional offices which are Telkom's Office of Digital Business Division Central Jakarta, office area of Telkom Yogyakarta special Region, and the regional office of Telkom Purwokerto Central Java.

\subsection{Research Variable and Measurement Variable}

To measure the variables in the questionnaire, this research using Likert scale 6 .

Using the following statement items:

Table 1

Indicators to Conduct the Measurement

\begin{tabular}{|c|c|c|}
\hline Variable & Item & Reference \\
\hline \multirow{4}{*}{$\begin{array}{l}\text { Institutional } \\
\text { Isomorphism }\end{array}$} & Have greatly benefitted & \multirow{4}{*}{$\begin{array}{l}\text { (Ramakrishnan et al., } \\
\text { 2010) }\end{array}$} \\
\hline & $\begin{array}{l}\text { Are favorably perceived by other firms } \\
\text { within the industry have greatly } \\
\text { benefitted }\end{array}$ & \\
\hline & Are favorably perceived by their suppliers & \\
\hline & $\begin{array}{l}\text { Are favorably perceived by their } \\
\text { customers }\end{array}$ & \\
\hline \multirow{4}{*}{$\begin{array}{l}\text { Competitive } \\
\text { Pressure }\end{array}$} & $\begin{array}{l}\text { The ease with which my } \\
\text { customers can }\end{array}$ & \multirow{4}{*}{$\begin{array}{l}\text { (Ramakrishnan et al., } \\
\text { 2010) }\end{array}$} \\
\hline & Increase competition & \\
\hline & $\begin{array}{l}\text { Increase the dominance of } \\
\text { competition }\end{array}$ & \\
\hline & $\begin{array}{l}\text { Business resources come from the } \\
\text { top four companies in the }\end{array}$ & \\
\hline \multirow[b]{2}{*}{ BI Purpose: } & $\begin{array}{l}\text { Understand the meaning } \\
\text { behind business }\end{array}$ & \\
\hline & $\begin{array}{l}\text { Understand the stock and } \\
\text { flow of business }\end{array}$ & \\
\hline
\end{tabular}




\begin{tabular}{|l|l|l|}
\cline { 2 - 2 } Insightfulness & $\begin{array}{l}\text { Identify and process the required } \\
\text { information into } \\
\text { condensed knowledge }\end{array}$ & $\begin{array}{l}\text { (Ramakrishnan } \text { et al. } \\
\text { 2010) }\end{array}$ \\
\cline { 1 - 2 } & $\begin{array}{l}\text { Understand current matters } \\
\text { and trends that affect the }\end{array}$ & \\
\hline
\end{tabular}

Indicators to Conduct the Measurement (continue)

\begin{tabular}{|c|c|c|}
\hline Variable & Item & Reference \\
\hline \multirow{3}{*}{$\begin{array}{l}\text { BI Purpose: } \\
\text { Consistency }\end{array}$} & $\begin{array}{l}\text { Provide consistent and reliable } \\
\text { data on which to base decisions }\end{array}$ & \multirow{3}{*}{$\begin{array}{l}\text { (Ramakrishnan et al., } \\
\text { 2010) }\end{array}$} \\
\hline & $\begin{array}{l}\text { Provide different stakeholders } \\
\text { with a single } \\
\text { consistent view of business }\end{array}$ & \\
\hline & $\begin{array}{l}\text { Provide a consolidated view of } \\
\text { information in the }\end{array}$ & \\
\hline \multirow{4}{*}{$\begin{array}{l}\text { Purpose } \\
\text { Organizational } \\
\text { Transformation }\end{array}$} & $\begin{array}{l}\text { Develop new business } \\
\text { models }\end{array}$ & \multirow{4}{*}{$\begin{array}{l}\text { (Ramakrishnan et al. } \\
\text { 2010) }\end{array}$} \\
\hline & $\begin{array}{l}\text { Redefine business } \\
\text { objectives }\end{array}$ & \\
\hline & $\begin{array}{l}\text { Change existing business } \\
\text { processes }\end{array}$ & \\
\hline & $\begin{array}{l}\text { Support strategic business } \\
\text { objectives }\end{array}$ & \\
\hline \multirow{7}{*}{ Problem Driven Strategy } & $\begin{array}{l}\text { Only specific data requested } \\
\text { by specific business units }\end{array}$ & \multirow{6}{*}{$\begin{array}{l}\text { (Ramakrishnan et al., } \\
\text { 2010) }\end{array}$} \\
\hline & $\begin{array}{l}\text { Only specific data necessary to } \\
\text { solve some specific problem }\end{array}$ & \\
\hline & $\begin{array}{l}\text { Application to determine BI } \\
\text { needs }\end{array}$ & \\
\hline & BI for a quick win solution & \\
\hline & $\begin{array}{l}\text { BI arose from business units } \\
\text { initiatives }\end{array}$ & \\
\hline & $\begin{array}{l}\text { Only specific data are required to } \\
\text { be integrated }\end{array}$ & \\
\hline & $\begin{array}{l}\text { Most of the data is used in the BI } \\
\text { process }\end{array}$ & \\
\hline
\end{tabular}




\begin{tabular}{|l|l|}
\cline { 1 - 2 } Comprehensive Strategy & $\begin{array}{l}\text { BI application program is } \\
\text { used to analyze data }\end{array}$ \\
\cline { 1 - 2 } $\begin{array}{l}\text { (Ramakrishnan } \text { et } \\
\text { al., 2010) } \\
\text { the organization give contribute }\end{array}$ & $\begin{array}{l}\text { Most of the business units in the } \\
\text { organization give contribute data }\end{array}$ \\
\hline
\end{tabular}

\section{a. Institutional Isomorphism}

Institutional isomorphism is a condition in which organizations within the same environment become more aligned without being efficient (DiMaggio and Powell, 1983). Measurement of institutional isomorphism is using four items from Ramakrishnan et al. (2010).

\section{b. Competitive Pressure}

Competitive Pressure is defined as the level of pressure that companies perceive from competitors in the industry (Zhu and Kramer, 2005). Given the pressures within one sector, the drive to become superior will be even higher. Measurement of competitive pressures is using four items from Ramakrishnan et al. (2010).

\section{c. BI Purpose: Insightfulness}

The purpose of insightfulness helps BI in gaining a better understanding of strategic matters and trends affecting their business (Gould, 2001). Measurements of BI insightfulness objectives are using four items from the Ramakrishnan et al. (2010).

\section{d. BI Purpose: Consistency}

This consistency objective relates to data governance and initiates a BI project to improve data quality and to eliminate inconsistencies (Eckerson, 2003). Measurement of BI purpose consistency is using four items from Ramakrishnan et al. (2010).

\section{e. BI Purpose: Organizational Transformation}

The purpose of organizational transformation can be interpreted as aligning the definition of business objectives and aligning these business goals with IT goals 
(Henderson and Venkatraman, 19932). Measurements of the BI purpose organizational transformation are using four items from Ramakrishnan et al. (2010).

\section{f. Problem Driven Strategy in BI Data Collection}

The problem-driven strategy involves the collection and integration of data to provide solutions for a particular business unit. This strategy is an application-centric approach where the applications needed to solve specific problems encourage the collection and integration of relevant data (Sen and Sinha, 2005). Measurement of problem-driven strategies in BI data collection is using six items from Ramakrishnan et al. (2010).

\section{g. Comprehensive Strategy in BI Data Collection}

A comprehensive strategy can be defined as the activity of collecting, integrating and storing all existing data in the organization into a single repository called a company as a comprehensive data warehouse (Ariyachandra, and Watson, 2005). The measurement of a comprehensive strategy in BI data collection uses four items from Ramakrishnan et al. (2010).

\subsection{Data Analysis Method}

\subsubsection{Structural Equation Model (SEM) Method}

This research is using the Structural Equation Model (SEM) method. With this method can improve the analysis technique in information system research. The SEM approach is a set of statistical techniques that enable testing of a relatively complex set of relationships simultaneously. The complex relationship is built between one or more dependent variables with one or more independent variables. Each dependent and independent variable can take the form of a factor or construct constructed from various indicators. Path analysis or SEM is not a method for finding causes, but methods applied to causal models are formulated by researchers based on knowledge and theoretical considerations (Hair et al., 1998).

The author used Smart PLS 3.0. software in this research. This software is 
able to process SEM-based research. It is easier but powerful and does not require various assumptions (Ghozali, 2012). The forms of equations that reflect hypothesis testing aimed at testing the influence of independent variables (institutional isomorphism and competitive pressure) through mediation variables (BI insightfulness objectives, consistency, and organizational transformation) of the dependent variable (problem driven strategy and comprehensive strategy) are:

The formula:

$$
\begin{aligned}
& \mathrm{INS}=\gamma 0+\gamma 1 \mathrm{ISI}+\varepsilon \\
& \mathrm{CST}=\gamma 0+\gamma 1 \mathrm{CMP}+\varepsilon \\
& \mathrm{OTR}=\gamma 0+\gamma 1 \mathrm{CMP}+\varepsilon \\
& \mathrm{PBD}=\beta 0+\beta 1 \mathrm{INS}+\varepsilon \\
& \mathrm{COM}=\beta 0+\beta 1 \mathrm{CST}+\varepsilon \\
& \mathrm{COM}=\beta 0+\beta 1 \mathrm{OTR}+\varepsilon
\end{aligned}
$$

Information:

$\gamma 0$ and $\beta 0=$ Constants $\gamma 1$ and $\beta 1=$ Coefficient

ISI

$$
=\text { Institutional isomorphism CMP = Competitive }
$$

pressure

INS

= BI Purpose insightfulness CST = BI Purpose consistency

OTR

= BI Purpose organizational transformation

PBD $=$ Problem driven strategy for $\mathrm{BI}$ data collection $\mathrm{COM}=$

Comprehensive strategy for BI data collection

$\varepsilon$ $=$ Disturbance error

\section{Result and Discussion}

\subsection{Statistics Descriptive}

This research conducted by distributing 150 questionnaires, 54 were not returned and not qualified, so this research could only use 96 of the returned questionnaires. According to Sekaran (2003), the minimum number of samples to 
obtain good results is 30 . The following analysis of the questionnaire survey distribution in Table 2:

Table 2

Classification of Data Collection

\begin{tabular}{|c|c|c|}
\hline Information & Quantity & $\%$ \\
\hline Distributed questionnaires & 150 & $100 \%$ \\
\hline Questionnaires did not return and unqualified & 54 & $36 \%$ \\
\hline Questionnaires qualified to be process & 96 & $64 \%$ \\
\hline Total & 150 & $100 \%$ \\
\hline
\end{tabular}

Source : Data Processed

\subsection{Outer Model Testing}

\subsubsection{Validity Test}

Validity test in this research uses convergent validity and discriminant validity. Convergent validity of the measurement model with a reflective indicator is judged by a correlation between item score or component score with construct score calculated by using PLS. Individual reflective sizes are said to be high if they correlate more than 0.5. (With significant 0.05 and T-statistics>1.64).

As for validity testing using discriminant validity is by comparing the square root of average variance extracted (AVE) value of each construct with the correlation between constructs with other constructs in the model. If the AVE square root of each construct is higher than the correlation value between the construct and the other constructs in the model, it has a good discriminant validity value. 
Table 3

Initial Item Loadings and AVE (Average Variance Extracted)

\begin{tabular}{|c|c|c|c|}
\hline Construct & Variable & Loading & AVE \\
\hline \multirow{4}{*}{ Institutional Isomorphism (ISI) } & Item ISI 1 & 0,7640 & \multirow{4}{*}{0,7551} \\
\hline & Item ISI 2 & 0,9132 & \\
\hline & Item ISI 3 & 0,9039 & \\
\hline & Item ISI 4 & 0,8863 & \\
\hline \multirow{4}{*}{ Competitive Pressure (CMP) } & Item CMP 1 & 0,6435 & \multirow{4}{*}{0,5450} \\
\hline & Item CMP 2 & 0,7581 & \\
\hline & Item CMP 3 & 0,7616 & \\
\hline & Item CMP 4 & 0,7818 & \\
\hline \multirow{4}{*}{ BI Purpose: Insightfulness (INS) } & Item INS 1 & 0,8445 & \multirow{4}{*}{0,6787} \\
\hline & Item INS 2 & 0,9431 & \\
\hline & Item INS 3 & 0,5675 & \\
\hline & Item INS 4 & 0,8888 & \\
\hline \multirow{4}{*}{ BI Purpose: Consistency (CST) } & Item CST 1 & 0,6301 & \multirow{4}{*}{0,7230} \\
\hline & Item CST 2 & 0,9249 & \\
\hline & Item CST 3 & 0,8817 & \\
\hline & Item CST 4 & 0,9825 & \\
\hline \multirow{4}{*}{$\begin{array}{l}\text { BI Purpose: Organizational } \\
\text { Transformation (OTR) }\end{array}$} & Item OTR 1 & 0,8083 & \multirow{4}{*}{0,7632} \\
\hline & Item OTR 2 & 0,9024 & \\
\hline & Item OTR 3 & 0,9089 & \\
\hline & Item OTR 4 & 0,8711 & \\
\hline \multirow{6}{*}{ Problem Driven Strategy (PBD) } & Item PBD 1 & 0,7313 & \multirow{6}{*}{0,5788} \\
\hline & Item PBD 2 & 0,7612 & \\
\hline & Item PBD 3 & 0,8279 & \\
\hline & Item PBD 4 & 0,7482 & \\
\hline & Item PBD 5 & 0,7672 & \\
\hline & Item PBD 6 & 0,7246 & \\
\hline \multirow[t]{4}{*}{ Comprehensive Strategy (COM) } & $\begin{array}{l}\text { Item COM } \\
\mathbf{1}\end{array}$ & 0,8718 & \multirow[t]{4}{*}{0,7352} \\
\hline & $\begin{array}{l}\text { Item COM } \\
\mathbf{2}\end{array}$ & 0,7819 & \\
\hline & $\begin{array}{l}\text { Item COM } \\
\mathbf{3}\end{array}$ & 0,8873 & \\
\hline & $\begin{array}{l}\text { Item COM } \\
\mathbf{4}\end{array}$ & 0,8843 & \\
\hline
\end{tabular}

Source: Data Processed 


\subsubsection{Reliability Test}

To measure the reliability construct data, it shows by composite reliability. The construct is declared reliable if the value of composite reliability is above 0.70 . While the instrument can be said reliable (reliable) if has coefficient Cronbach alpha> 0.60. The value of Cronbach alpha is usually accepted is 0.60 to 0.70 (Ghozali, 2006). From the results of a reliability test shows the seriousness of respondents in answering all items of research statement with each item value of Cronbach alpha is $>0.60$.

Table 4

Composite Reliability dan Cronbach's Alpha

\begin{tabular}{|l|r|r|c|}
\hline Code & Composite Reliability & Cronbachs Alpha & Information \\
\hline CMP & 0,8265 & 0,7321 & Reliable \\
\hline COM & 0,9172 & 0,8793 & Reliable \\
\hline CST & 0,9109 & 0,8644 & Reliable \\
\hline INS & 0,8911 & 0,8329 & Reliable \\
\hline ISI & 0,9246 & 0,8905 & Reliable \\
\hline OTR & 0,9279 & 0,8958 & Reliable \\
\hline PBD & 0,8917 & 0,8633 & Reliable \\
\hline
\end{tabular}

Source: Data Processed

\subsection{Hypothesis Testing}

To examine the proposed hypothesis, we can see the amount of T-statistics value. The limit to reject and accept the proposed hypothesis is T-statistics $>1.64$ where if the value of $\mathrm{t}$ is more significant than 1.64 then the hypothesis will be accepted or in other words has a positive effect. The result of T-statistic estimation can be seen on the result of inner weight in table 4.

Hypothesis 1 states that institutional isomorphism has a positive and significant relationship to BI purpose insightfulness which is shown with a T-statistic value of 7,340 is more significant than T-count is 1.64 so the hypothesis 1 accepted. Hypothesis 2 states that institutional isomorphism has a positive and significant 
relationship to BI consistency purpose which is shown with T-statistic value 5,571 bigger than T-count is 1.64 , so hypothesis 2 is accepted.

Hypothesis 3 states that competitive pressure has a positive and significant relation to BI purpose organizational transformation which is shown with a $\mathrm{T}$-statistic value of 9.555 is bigger than T-count is 1.64 , so hypothesis 3 is accepted. Hypothesis 4 states that BI purpose insightfulness has a positive and significant relation to problem driven strategy in BI data collection is shown with a T-statistic value of 6.563 greater than T-count is 1.64 so the hypothesis 4 is accepted.

Hypothesis 5 states that BI purpose consistency does not have a positive and significant relation to a comprehensive strategy in BI data collection which is shown with a T-statistic value of 1.572 which is less than T-count of 1.64 so the hypothesis 5 is not accepted. Hypothesis 6 states that the goal of BI organizational transformation has a positive and significant relation to a comprehensive strategy in BI data collection indicated by a T-statistic value of 3.764 is greater than T-count is 1.64 so the hypothesis 6 is accepted.

Table 5

Inner Weights

\begin{tabular}{|l|c|c|c|}
\hline & $\boldsymbol{\alpha}$ (alpha) & T Statistics (|O/STERR|) & Information \\
\hline ISI -> INS & $5 \%$ & 7,340 & Accepted \\
\hline ISI -> CST & $5 \%$ & 5,571 & Accepted \\
\hline CMP -> OTR & $5 \%$ & 9,555 & Accepted \\
\hline INS -> PBD & $5 \%$ & 6,563 & Accepted \\
\hline CST -> COM & $5 \%$ & 1,572 & Not Accepted \\
\hline OTR -> COM & $5 \%$ & 3,764 & Accepted \\
\hline
\end{tabular}

Source: Data Processed

4.4 The result of Hypothesis Testing and Discussion

H1. Institutional isomorphism has a positive relation to the BI purpose insightfulness. 
Table 5 shows that the $\alpha$ (alpha) is 5\% and hypothesis affects between ISI and INS is strongly significant with P-value of 0,000 and T-statistics 7,340 (> 1.64). Based on the results of hypothesis testing above it can be concluded that institutional isomorphism has a positive and significant influence on BI purpose insightfulness so that the first hypothesis of this study is accepted. The results of this study are not by research conducted by Ramakrishnan (2010) that institutional isomorphism does not have a positive relation to the BI purpose insightfulness. Thus H1 in this study which states that institutional isomorphism has a positive relationship on BI purpose insightfulness. This means that the higher level of institutional isomorphism experienced in the organization, so the understanding of the strategic things and trends that affect their business would be increased.

H2. Institutional isomorphism has a positive relation to the BI purpose consistency.

Table 5 shows that the $\alpha$ (alpha) is $5 \%$ and hypothesis affects between ISI and CST is significantly strong with P-value 0.000 and T-statistic 5,571 (> 1.64). Based on the results of hypothesis testing above it can be concluded that institutional isomorphism has a positive and significant relation to BI purpose consistency so that the second hypothesis of this study is accepted. The results of this study are following research conducted by Ramakrishnan (2010) that institutional isomorphism affects the BI purpose consistency. Thus $\mathrm{H} 2$ in this study which states that institutional isomorphism has a positive relation to BI purpose consistency. This means that the higher level of institutional isomorphism experienced in the organization, so the quality data and consistency in providing would be more trusted. H3. BI purpose competitive pressure has a positive relation to the BI purpose organizational transformation.

Table 5 shows that the $\alpha$ (alpha) is $5 \%$ and the hypothesis affects between CMP and OTR is significantly strong with P-value being 0.000 and T-statistic 9.555 (>1.64). Based on the results of hypothesis testing above it can be concluded that competitive pressure has a positive and significant relation to BI purpose 
organizational transformation so that the third hypothesis of this study is accepted. The results of this study are not following research conducted by Ramakrishnan (2010) that competitive pressure does not have a positive relation to the BI purpose organizational transformation. Thus $\mathrm{H} 3$ in this study which states that competitive pressure has a positive relationship on the BI purpose organizational transformation. This means that the higher pressure perceived level by an organization in an industry would directly increase the level of business objectives needs by information technology goals.

H4. BI purpose insightfulness has a positive relation to the problem-driven strategy in BI data collection.

Table 5 shows that the $\alpha$ (alpha) is $5 \%$ and hypothesis affects between INS and PBD is strongly significant with P-value of 0,000 and T-statistic 6,563 (> 1.64). Based on the results of hypothesis testing above it can be concluded that the BI purpose insightfulness has a positive and significant relation to problem driven strategy in BI data collection so that the fourth hypothesis of this study is accepted. The results of this study are not in accordance with research conducted by Ramakrishnan (2010) that the BI purpose insightfulness does not have a positive relation to problem driven strategy in BI data collection. Thus $\mathrm{H} 4$ in this study which states that the BI purpose insightfulness has a positive relation to the problem-driven strategy in BI data collection. This means that the higher understanding level about strategic things and trends in the business would give the best solution for the organization.

H5. BI's consistency objectives have a positive relation to the comprehensive strategy in BI data collection.

Table 5 shows that the $\alpha$ (alpha) is $5 \%$ and hypothesis the effects of CST and COM is not significant with P-value 0.117 and T-statistic 1.572 (> 1.64). Based on the results of hypothesis testing, it can be concluded that BI purpose consistency does not have a positive and significant relation to BI comprehensive data collection 
strategy so that the fifth hypothesis of this research is not accepted. The results of this study it is not in accordance with research conducted by Ramakrishnan (2010) that the BI purpose consistency has relation to a comprehensive strategy in BI data collection. Thus, H5 in this study stated that the BI purpose consistency does not have positive relationship to the comprehensive strategy in BI data collection. This means that more consistent and good quality of data generated by the organization does not improve the quality of the data collected, integrated and stored in a comprehensive strategy

H6. The goals of BI organizational transformation have a positive relation to the comprehensive strategy in BI data collection.

Table 5 shows that with the $\alpha$ (alpha) is 5\% and hypothesis the effect between OTR and COM is not significant with P-value is 0.000 and T-statistic 3,764 (> 1.64). Based on the results of hypothesis testing above it can be concluded that the BI purpose organizational transformation has a positive and significant relation to comprehensive strategy BI data collection so that the fifth hypothesis of this study is accepted. The results of this study are in accordance with research conducted by Ramakrishnan (2010) that the objectives of the BI transformation of the organization have a relation to the comprehensive strategy in BI data collection. Thus, H6 in this study stated that the BI purpose organizational transformation positive relation to a comprehensive strategy in BI data collection. This means that the more aligned the business objectives with the goals of information technology in the organization that run comprehensive strategy, so their quality of data was collected and integrated into would be better.

\section{Conclusion, Implication, and Limitation}

\subsection{Conclusion}

The results of hypothesis testing 1 to 3 indicate that only institutional isomorphism toward BI's goal of consistency alone has a positive relation. This is in 
accordance with the results of previous research conducted by Ramakrishnan et al. (2010). As for institutional relations and competitive pressure on BI purpose insightfulness, and organizational transformation the results contradict Ramakrishnan et al. (2010) research or in other words there is no positive effect.

For testing hypotheses, 4 to 6 indicates that only the BI purpose of organizational transformation of a comprehensive data collection strategy is consistent with the results of previous research conducted by Ramakrishnan et al. (2010). Another hypothesis, the relation between BI purpose insightfulness and BI purpose consistency with the problem-driven strategy in BI data collection was different from previous research that conducted by Ramakrishnan et al. (2010).

Institutional isomorphism can arise from two conditions, the first arising from political influence and the need for legitimacy (DiMagio and Powell, 1983) and the second comes from Organizations try to cope with uncertainty by mimicking the actions of other organizations that they perceive to be successful within a similar environment (DiMaggio and Powell, 1983; Liang et al., 2007). The institutional isomorphism pressure can provide a good understanding of the strategic things and trends that will affect the business. Also, can encourage organizations to obtain highquality data and avoid inconsistencies.

Competitive pressure is the level of pressure perceived by a company. Competitive pressures can also influence the selection of different strategies within organizations (Bradford and Florin, 2003). Therefore, the existence of competitive pressure can encourage companies to continue to review the strategy and re-align the definition of business objectives.

The purpose of BI in this study is divided into three, the first BI purpose insightfulness, BI purpose consistency, and BI purpose organizational transformation. BI purpose insightfulness can be interpreted to understand the current business conditions and to get benefits for proponents of the judgment. This is in line with problem driven strategies with problem-solving approaches to find a solution, so the better understanding of business conditions the benefits of decision support 
and problem-solving will also improve. Then the next BI purpose is organizational transformation, can be defined as the development of new business models to take advantage of the market to achieve the competitive advantage of industry. This is in line with a comprehensive strategy that holds all information, integrates, and stores it into a single repository. Therefore, the better the development of a business model undertaken by a company in the industry then the data and information obtained, integrated, and stored as a basis for decision making will also be better. The last BI purpose is consistency, can be interpreted to provide a view of the state of the company to stakeholders. The data required is of high quality to avoid inconsistencies. From the results of data obtained shows that this is not in line with one of BI's strategy in data collection, that is with a comprehensive approach, and it seems not only by improving the data only to support this comprehensive strategy. Other factors can also influence this strategy since in this comprehensive strategy it consists of a long process sequence starting from collecting, integrating and storing it to a data warehouse.

The process of collecting and storing data and the capability of securing data warehousing becomes the main focus that needs to be considered as it requires the capacity for large data. That way all the data that has been collected can be managed well in the process of collecting, integrating it into a data warehouse. So, the data owner can be used by the user as a basis in decision making.

\subsection{Implications}

The results of this study provide new insights for practitioners, especially managers and employees who have authority to decide business intelligence, and hopefully can lead to their perspective that business intelligence is very helpful in the process of decision-making strategies in an organization, especially for PT. Telekomunikasi Indonesia Tbk. Besides that, this research hopefully can give more advantages to accounting information systems and decision support systems major. And also, would provide opportunities for other researchers in the future. 


\subsection{Limitations}

Limitations in this study are the sample is too small with only 96 respondents from 3 regional offices in 3 different provinces. One of the most problems is the respondents did not return the questionnaire, and they did not make available in the office. Besides that, this research only focuses on the telecommunications industry, without discussing the competitors that may have implemented business intelligence.

The results of this research explain that managers at Telekomunikasi Indonesia Tbk. implemented and used business intelligence in their business process. Both of these strategies have the same benefits, but a comprehensive BI data collection strategy that is influenced by BI purpose consistency did not have a positive relation. Improving the implementation of BI projects to make good quality data and eliminating inconsistencies will be the best solution for BI's data collection strategy in Telekomunikasi Indonesia Tbk. to run its business process.

The future research can use more respondents, for example, all of Telkom's regional offices in Indonesia so that it can generalize research, institutional isomorphism, and competitive pressure. Thus, the limitations of this study provide an opportunity future research to examine the relation of BI purpose except from the three purposes that discussed in this study, BI data collection, and the success of BI implementation.

\section{References}

Anderson-Lehman, R., Watson, H. J., Wixom, B. H., and Hoffer, J. A. (2004). Continental Airlines Flies High with Real-Time Business Intelligence. MIS Quarterly Executive (3:4), pp. 163-176.

Ariyachandra, T., and Watson, H. J. (2005). Key Factors in Selecting a Data Warehouse Architecture. Business Intelligence Journal, pp. 19-27.

Bergeron, F., Raymond, L., and Rivard, S. (2004). Ideal Patterns of Strategic Alignment and Business Performance. Information \& Management 41, pp. 1003-1020.

Cooper, B. L., Watson, H. J., Wixom, B. H., and Goodhue, D. L. (2000). Data Warehousing Supports Corporate Strategy at First American Corporation. MIS Quarterly (24:4), pp. 547-567. 
DiMaggio, P. J., and Powell, W. W. (1983). The Iron Cage Revisited: Institutional Isomorphism and Collective Rationality in Organizational Fields. American Sociological Review (48:2), pp. 147-160.

Eckerson, W. (2006). New Ways to Organize the BI Team. Business Intelligence Journal First Quarter(11:1), pp. 43-48.

Ettlie, J. E., and Bridges, W. P. (1982). Environmental Uncertainty and Organizational Technology Policy. IEEE Transactions on Engineering Management (29:1), pp. 2-10.

Ghozali, I. (2006). Structural Equation Modeling Metode Alternatif dengan PLS Edition 2nd. Semarang: Agency Publisher of Diponegoro University.

Ghozali, I. (2012). Konsep, Teknik dan Aplikasi Partial Least Square. Semarang: Agency Publisher of Diponegoro University.

Hair, J. F., Anderson, R. L., Tatham, R., and Black, W. (1998). Multivariate Data Analysis $5_{\text {th }}$ ed. L. New York: Prentice Hall. Prentice Hal

Henderson, J. C., and Venkatraman, N. (1993). Strategic Alignment: Leveraging InformationTechnology for Transforming Organizations. IBM Systems Journal (32:1), pp. 4-16.

Lai, K., Wong, C. W. Y., and Cheng, T. C. E. (2006). Institutional Isomorphism and the Adoption of Information Technology for Supply Chain Management. Computers in Industry (57), pp. 93-98.

Leon, A. (2008). ERP Demystified (Second Edition). New Delhi: Tata McGraw- Hill.

Massa, S., and Testa, S. (2005). Data Warehouse-in-Practice: Exploring the Function of Expectations in Organizational Outcomes. Information \& Management (42), pp. 709718.

Mata, F. J., Fuerst, W. L., and Barney, J. B. (1995). Information Technology and Sustained Competitive Advantage: A Resource-Based Analysis. MIS Quarterly (19:4), pp. 487506.

Moss, L. T., and Atre, S. (2007). Business Intelligence Roadmap. Boston: Pearson Education Inc.

Olszak, C. M., and Ziemba, E. (2006). Business Intelligence Systems in the Holistic Infrastructure Development Supporting Decision-Making in Organizations. Interdisciplinary Journal of Information, Knowledge, and Management (1), pp. 47-58.

Porter, M. E., and Millar, V. (1985). How Information Gives You Competitive Advantage. Harvard Business Review (63:4), pp. 149-160. 
Powell, W. W., and DiMaggio, P. J. (1991). The New Institutionalism in Organizational Analysis. Chicago: University of Chicago Press.

Ramakrishnan, T., Jones, M.C., and Sidorova, A. (2010). Factors Influencing Business Intelligence (BI) Data Collection Strategies: An Empirical Investigation. College of Business, University of North Texas, pp. 1-11.

Robertson, T. S., and Gatignon, H. . (n.d.). Competitive Effects on Technology Diffusion. Journal of Marketing (50), pp. 1-12.

Thong, J. Y. L., Yap, C., Raman, K. S. (1996). Top Management Support, External Expertise and Information Systems Implementation in Small Businesses. Information Systems Research (7:2), pp. 248-269.

Telkom. (2014, August 18th). www.telkom.co.id. Retrieved February 24th, 2015, from Telekomunikasi Indonesia Tbk.: http://www.telkom.co.id/telkom- bangun-10-ribuwifi- ngebut-100-mbps.html

Turban, E. et al. (2005). Decision Support Systems and Intelligent Systems 7th Ed.

New Jersey: Pearson Education.

Watson, H. J., and Haley, B. J. (1998). Managerial Considerations.

Communications of the ACM (41:9), pp. 32-37.

Zhu, K., and Kraemer, K. L. (2005). Post-Adoption Variations in Usage and Value of EBusiness by Organizations: Cross-Country Evidence from the Retail Industry. Information Systems Research (16:1), pp. 61-84. 


\section{Appendix}

Research Result

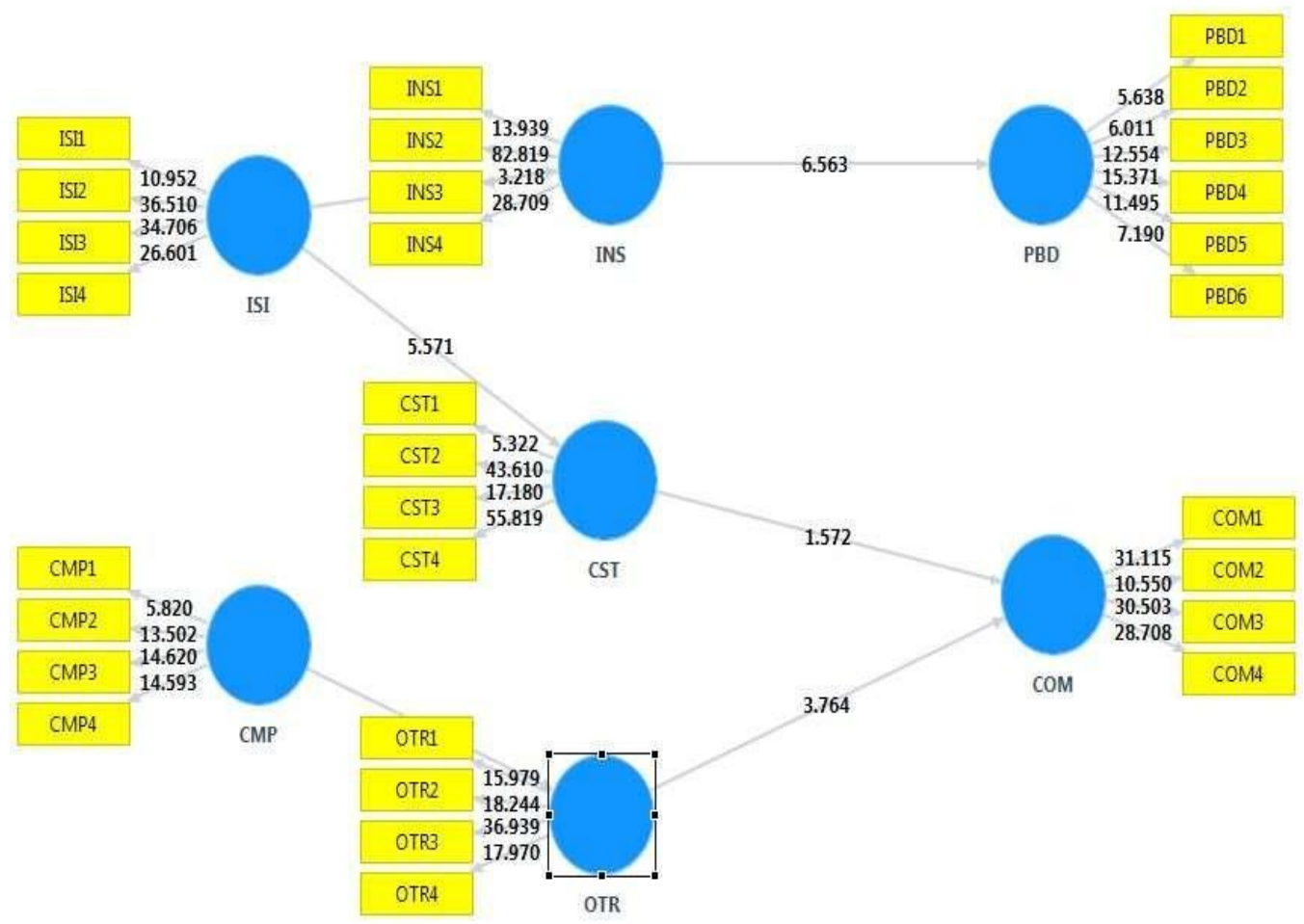


The Indonesian Journal of Accounting Research - May, Vol. 20, No.2, 2017

intentionally blank 